\title{
In Search of Religious Modernity: Conversion to Islam in Interwar Berlin
}

\author{
Gerdien Jonker
}

\section{Introduction}

Throughout the interwar period, Berlin experienced the devastating effects of increasing globalization; in the aftermath of a war it had not started, it found that, nonetheless, it had to pay the costs. Towards the end of the war, which involved the loss of lives on a hitherto unknown scale, the Prussian, Ottoman, Habsburg, and Russian Empires were abolished. Russia went through a revolution that changed the political topography of Eastern Europe and inspired dreams of revolution elsewhere; Hungary was occupied and forced into Communism. Poland drew new borders, with deadly implications for the border populations, the former Habsburg Empire was cut down into minute parcels, and France, the country in which a large part of the war had been fought, emerged drastically mutilated. ${ }^{1}$

After the armistice was declared, Germany lived through a period of serious political destabilization. Most Germans failed to comprehend why they had been defeated, and it did not help that the political classes refused to acknowledge this. ${ }^{2}$ National pride was at stake. Returning divisions formed paramilitary organizations and terrorized Germany for at least four years. Between 1918 and 1922 the ultra-right created havoc in the Rhine area, the Baltic countries, and Schlesien. In Munich, a Communist regime took power. In Kiel, Hamburg, and Berlin socialist uprisings and uncontrolled street fighting created great political tension. ${ }^{3}$ From the far right to the far left, the country groped for a return to its "original" state; it invented as it went along a

1 Jane Burbank and Frederick Cooper, "War and Revolution in a World of Empires: 1914-1945," in Empires in World History, ed. Jane Burbank et al. (Princeton, NJ: Princeton University Press, 2010), 369-413.

2 John Horne and Alan Kramer, German Atrocities: A History of Denial (New Haven and London: Yale University Press, 2001), 327-400; Eric Hobsbawn, The Age of Extremes: A History of the World 1914-1991 (New York: Vintage Books, 1994).

3 Vanessa Conze, Das Europa der Deutschen: Ideen vonEuropain Deutschland zwischen Reichstradit-ion und Westorientierung (1920-1970) (Munich: Oldenbourg Wissenschaftsverlag, 2005), 25-100.

(C) GERDIEN JONKER, 2016 | DOI 10.1163/9789004301979_003 
Deutschheit (German-ness) that resulted in visions of "anti-modern modernity" 4 and vehemently opposed the democratic but feeble Weimar government.

A spiritual vacuum across Europe accompanied the political crisis. Official religion, both in its Lutheran and Catholic form, quickly lost authority. The Kaiser had been a symbol of Protestantism and when he left the country the Lutheran church was widely felt to be devoid of meaning. Likewise, the occupation of the Rhineland and the refusal of the victorious powers to unite Germany with Austria contradicted the traditional German Catholic selfunderstanding of the Christliches Abendland (Christian Occident). ${ }^{5}$ As a result, many people turned their backs on the German churches and went in search of spiritual alternatives; ${ }^{6}$ it helped that the trend toward globalization had already enhanced the level of knowledge and respect for other belief systems. In the age of modernity, the awareness of other religions not only meant the enhancement of knowledge, it also implied the freedom to choose between them. Along with the study of religious texts, theosophy in particular encouraged the study of religions through encounter, experience, and conversion. ${ }^{7}$ In the aftermath of the war, all these elements joined to create a fertile breeding ground for religious experiment. Foreign missionaries with a fresh message were welcomed, and the Weimar Republic became a stage for Hindu, Buddhist, Muslim, and alternative Christian missions.

After 1923, when a fragile equilibrium began to take hold, Berlin quickly became the cultural capital of continental Europe. A magnet for artists, writers, cinematographs, and actors, it became the avant-garde center of European modernity. Journalists representing the main European and American dailies joined ranks in order to report about revolutionary progress and its backlashes. ${ }^{8}$ As many as 500,000 refugees from Russia flooded Berlin on their way to the Americas, among them the Russian-Jewish intelligentsia and revolutionary art-

4 Anselm Doering-Manteuffel, "Suchbewegungeninder Moderne. Religion im politischen Feldder Weimarer Republik," in Religion und Gesellschaft. Europa im 20. Jahrhundert, ed. Friedrich Graf and Klaus Große Kracht (Köln/Weimar/Wien: Böhlau, 2007), 177.

5 Doering-Manteuffel, “Suchbewegungen," 179.

6 Michael Klöckner and Udo Tworuschka, Religionen in Deutschland. Kirchen, GlaubensGemeinschaften, Sekten (Munich: Olzog Verlag, 1994).

7 Ulrich Linse, "Lebensreform und Reformreligionen," in Die Lebensreform. Entwürfe der Neugestaltung von Leben und Kunst umigoo, ed. Kai Buchholz et al. (Darmstadt: Haeussermedia, 2001), 193-199; Helmut Zander, Anthroposophie in Deutschland. Theosophische Weltanschauung und gesellschaftliche Praxis 1884-1945 (Göttingen: Vandenhoeck and Ruprecht,2007), 33-51.

8 Sigrid Bauschinger, “The Berlin Moderns: Else Lasker-Schülerand, 'Café Culture," in Berlin Metropolis, ed. Emily D. Bilsky (New York: Jewish Museum, 2000), 58-102. 
ists whom the revolution had betrayed. ${ }^{9}$ This amalgam of people created an extraordinary creative potential. For some time, Berlin's large apartment houses were inhabited by a floating bohemia that was critical of European civilization, sympathized with revolution, and wrote the books, produced the films, and created the art that today are among the classics of modern European art. The proponents of anti-modern modernity, the conservative elites, the National Socialists, and the right-wing paramilitary despised and hated them. ${ }^{10}$

This constellation served as the local setting in which students, writers, missionaries, and revolutionaries from Muslim countries, those who constituted the Muslim community in interwar Berlin, interacted with their host society. From yet another angle, they can be seen as part of the same globalization disaster, in which the Muslim world had perceived Germany as a friend. During the Great War the Ottoman Empire had been Germany's comrade-in-arms; Indian, Tatar, and Arab revolutionaries had been trained by German and Ottoman officers to inspire insurgencies against British colonial administrations; POw camps outside Berlin had gathered some 20,00o French, British, and Russian Muslim prisoners of war. A mosque had been erected to serve their religious needs, and a group of Tatars, reluctant to join the revolution, built the first organizational structures. For some time, the financial crash kept rents and the cost of living low, and this made university study in Berlin attractive. Thus, Berlin became the stage for a nascent Muslim community because it offered a local setting that favored the development of global, pan-Islamic ideas. ${ }^{11}$ These were voiced in a large range of Arabic, Persian, Tatar, French, and German periodicals, papers, and books that were all written, printed and published in Berlin. ${ }^{12}$

For ten years, from 1923 to January 1933, these people turned Berlin into a melting pot in which extremes prevailed: extreme bourse crashes, extreme political instability, extreme outpourings of creativity, and extreme missionary

Karl Schlögel, Das russische Berlin. Ostbahnhof Europas (Munich: Panthon, 2007); Verena Dohrn and Gertrud Pickhan, Transitund Transformation. Osteuropäisch-jüdische Migranten in Berlin 1918-1939 (Göttingen: Wallstein, 2012).

10 Werner Maser, Adolf Hitler. Mein Kampf. Geschichte. Auszüge. Kommentare (Rastatt: Moewig, 1981); Ernst von Salomon, Der Fragebogen (Hamburg: Rowohlt, 1961).

11 Gerhard Höpp, "Zwischen Moschee und Demonstration. Muslime in Berlin, 1922-1930," Moslemische Revue (1990): 135-146, (1990): 230-223, (1991): 12-19; Gerhard Höpp. 'Die Sache ist von immenser Wichtigkeit.' Arabische Studenten in Berlin (Ms, Höpp Archive), 1990; Iskander Giljazov, Muslime in Deutschland: Von den zwanziger Jahren zum 'Islamische Faktor' während des 2. Weltkrieges (MS, Höpp Archive), 1989.

12 Gerhard Höpp. Arabische und islamische Periodika in Berlin und Brandenburg 1915-1945. Geschichtlicher Abriß und Bibliographie (Berlin: Das Arabische Buch, 1994). 
activities. On 30 January 1933 when the fascist National Socialists came to power, the pluralistic society engendered by the Weimar Republic was devastated. The new regime forged political stability through the persecution of anyone who did not conform to its idea of German-ness, and it targeted communists and socialists, artists and homosexuals, political opponents, gypsies, and Jews. The remaining opponents left the country. The rest of the population conformed politically, taking membership in the Nazi party or becoming active in one of the many Nazi sub-organizations. ${ }^{13}$ The influx of migrants was stopped. Foreigners were scrutinized and refused residency permits unless they conformed to Nazi politics. Alternative religious groups were closed down or brought under government control. Muslim organizations in Berlin faced the same choices as their German neighbors: Muslim Communists fled the country, the rest, again, conformed to, or cooperated with the prevailing regime.

In this study I address Muslim missionaries together with those they targeted: Germans who during these turbulent years chose to become Muslims. Starting in 1922, when the first Muslim mission commenced, this study ends at the moment Germany entered the next war and the last missionary left the country. Within these limits, I trace Muslim missionary activities and map the different responses to them.

For two Muslim organizations especially, the establishment of a mission among the Europeans was central to their endeavor to ameliorate the situation in their home country of British India. The Islamische Gemeinde zu Berlin e.V. (IGB), invited Europeans to embrace Islam and join their revolutionary struggle. For the Ahmadiyya Anjumani-Isha'ati-Islam (AAII), missionary work among the Europeans implied the creation of a trans-cultural religious space in which Indians and Germans met as equals and sought individual progress. ${ }^{14}$ Those were very different aims. In their quest for freedom, the IG B did not exclude the use of weapons, whereas the Ahmadiyya followed Gandhi and developed methods of non-violence. For the AAII, mission among the Europeans was the primary aim and its missionaries went about it in ways that

13 In 1933, when the NSDAP came to power, this party already counted 2.5 million members. To avoid the influx of nominal members, the regime put a stop on new memberships until 1937. Once this was removed, membership mounted to 11.5 million of a total population of 66 million inhabitants. Available online: http://www.bundesarchiv.de/oeffentlichkeitsarbeit/ bilder_dokumente/oo757/index-11.html.de.

14 The competing Ahmadiyya Qadiani branch tried to do the same but failed for a variety of reasons. See Gerdien Jonker "A Laboratory of Modernity—The Ahmadiyya Mission in Interwar Europe," Journal of Muslims in Europe 3 (2014): 1-25; Missionizing Europe: The Ahmadiyya Quest for Religious Progress 1900-1965 (Leiden: Brill, 2015). 
were highly professional, whereas the IG B first of all ministered to Muslim émigrés because what it needed was political solidarity, not converts in search of personal redemption. As a result, the two organizations were in constant competition. ${ }^{15}$

While introducing the reader to a range of convert biographies, in this contribution I look for interfaces between different ideas of, and searches for, modernity. During the interwar period, visions of and experiments with man's progress in the name of modernity were at the heart of the transnational exchange, and for very different reasons: converting to Islam was considered a legitimate and widely accepted means towards that aim. Germans who converted to Islam covered a wide societal and political range, from revolutionaries and avant-garde artists, to conservative university professors and orientalists, to sympathizers and members of the Nazi Party, and included both Christians and Jews. Their imaginative conceptions of Islam differed accordingly and ranged from rational religion to mysticism, from a religion fit for world revolution to one with a penchant towards the military. Apart from Lev Nussimbaum and Leopold Weiss, this group has not yet been the subject of academic research. This study therefore makes a novel contribution.

Missionary activities could be traced in registry files, mission journals, the archives of the Foreign Office, as well as in the scant remains of the Ahmadiyya Mosque Archive. Tracing the convert biographies is more difficult. Some converts left only a name in the registry files, others added a photograph, still others a conversion narrative. Some wrote under a pseudonym, others changed their Christian or Jewish names for a Muslim surname. All this makes access to their lives extremely difficult. In some cases, where it was possible to establish an original name, we found traces in the national library, sometimes also in the NSDAP membership files.

In the framework of this volume on European (trans)cultural history we ask what the missionary endeavor and its German responses added to the global exchange. Did the interaction engender fresh ideas and a transfer of knowledge? Did it manage to break down cultural borders? To find answers we scrutinize the meeting between missionaries and converts while introducing the term religious modernity to describe the character of that meeting point. Our assumption is that there were various interfaces between the missionaries and modernity and that experimentation with religion played a major role in the ensuing communication.

15 Jonker, “A Laboratory of Modernity”; Jonker, Missionizing Europe. 


\section{Leadership in the Missionary Field}

Let us first focus on the nascent Muslim community in Berlin. In 1922, there were already sixteen organizations in existence. ${ }^{16}$ By 1932 we count twenty political organizations with the aim of liberating Muslim home countries from colonial rule, six student organizations, and six different religious organizations that represented as many as 46 different Muslim 'nations' in their ranks. ${ }^{17}$ Situated in a non-Muslim country, leadership of this international community could only be symbolic and needed religious legitimacy in order to function. Once created, it was also subject to intense competition, in which political, dogmatic, and generational differences all played a part. In order to foster panIslamic aspirations among Muslims in Berlin, it was necessary to unite the local community under one leadership. The reality of their diversity, however, forged a different course, and created several competing Muslim leaders who incidentally also employed different missionary styles. Because these men represented the 'face' of Islam in Germany, and official interaction with German society focused on them, I introduce each briefly here.

Any attempt to create a 'Who's Who' of Muslim leadership and missionaries in interwar Berlin inevitably calls to mind Gilbert Achcar's ordering of the different political positions in the Arab world between 1933 and $1947 .{ }^{18}$ Already anticipating the Arab political scene of the 1930s, Weimar Berlin collected western-oriented liberals, Marxists, nationalists, reactionaries, and/or fundamentalist pan-Islamists. In contrast to Achcar's findings, however, in the 1930s most Muslim organizations in Berlin gravitated towards fascism, a trend that must be considered against the background of the oppressive German politics. Whereas the liberal administration of the Weimar Republic set the scene for political and cultural diversity, the Nazi regime only tolerated its own worldview, though they created a framework in which Muslim fascist responses could become articulate.

In the order of their appearance on the Berlin stage, we first meet Abdul Jabbar Kheiri (1880-1958), who, during World War I acted as an agitator against the British in the service of the Germans, and in 1922 united Berlin's Muslim population in the IG B. An Indian revolutionary working towards the liberation of the Muslim world, if need be by violent means, Kheiri combined Marxism with pan-Islamism. Global change, or so his philosophy seems to hold, had to

\footnotetext{
16 Giljazov, Muslime in Deutschland; Höpp, Zwischen Moschee und Demonstration.

17 Jonker, Missionising Europe.

18 Gilbert Achcar. Les Arabes et la Shoah (Paris: Actes sud, 2009).
} 
come about through world revolution. ${ }^{19}$ When founding the IGB, his political involvement and his mission among the Europeans seem to have closely interacted. The documents in the archive of the Foreign Office that deal with him consistently label him a Bolshevik. ${ }^{20}$ In the eyes of his community, it made him a hero: a photograph in the file, dated 1925 , reveals an authoritative man in turban and loose robes, carried in triumph on the shoulders of young men from his community.

In 1922, Kheiri also launched a mission journal, Der Islam: Ein Wegweiser zur Rettung und zum Wiederaufbau (Islam: A guide for rescue and restoring). Here, for the first time in German history, Germans were invited to embrace Islam as a way to join the world revolution. Christianity cannot play that role, the text warns, because clearly it is a concoction of fantasy and lies, full of disdain for women. Only Islam holds the key to the main concerns of the day: "world peace," "global freedom," "justice," "happiness," "development," and "progress."21 In this text, key concepts of modernity (progress, development) are closely joined to global concerns: seen from this angle, liberation of the Muslim world from colonial oppression would bring world peace, justice, and happiness. If peace and justice was what the Germans were looking for, or so the text seems to suggest, they should join the struggle and become part of the worldwide Muslim community.

The second leader who dominated these early years was Khwaja Sadr-udDin (1881-1981), a missionary trained by the Ahmadiyya of Lahore. He arrived in 1923 and built a mosque in Wilmersdorf for which he was much envied and which for a long time was the only mosque in Berlin. Thus responding to pressing needs, Sadr-ud-Din refrained from founding his own religious organization. Instead he used his energies to set up a mission post and in 1924 also launched the mission journal Moslemische Revue, in which he introduced himself as a western-oriented Muslim intellectual interested in starting a dialog with European intellectuals on the topic of peace and personal progress. His mission goal was simple and straightforward. From 1925 onwards, every issue featured 'modern' aspects of the religion and explained how to join:

To become a Muslim, a ceremony is not required. Islam is not only a rational, widely spread and practical religion, it is also in full harmony

19 AA/2 (Oct. 1928); Abdul Jabbar Kheiri, Sowjet-Rußland und die Völker der Welt (Petrograd: Verlag Kommunistische Internationale, 1924).

$20 \quad \mathrm{AA} / 1, \mathrm{AA} / 2$.

21 Der Islam. Ein Wegweiser zur Rettung und zur Wiederaufbau, ed. Jabbar Kheiri and Sattar Kheiri, 1 (1922), 17. 
with the natural human disposition. Every child is born with it. This is why becoming a Muslim does not require a transformation. One can be a Muslim without telling anyone...22

This indeed was a totally different message than that which the IG B advocated. Progress, or so the Ahmadiyya philosophy ran, was inherent in personal progress and a key concept of Islam. Except for their contribution to world pacifism (see below), the Ahmadiyya did not target global politics. Rather, they tried to create a transnational space for the meeting of different cultures. ${ }^{23}$ To Germans trying to sort out their present spiritual turmoil the Ahmadiyya mission goals indeed offered an intellectual and emotional meeting ground, one in which different approaches to European modernity, especially the concept of Lebensreform (Life reform) could be brought forward, questioned, and linked to Islam and Muslim modernization.

In 1927, a third leader entered the Berlin stage, one who, in only a few years time, superseded Kheiri, opening up the Arab community towards a more practical, western-oriented liberalism. Arriving as a student in 1923, Mohammed Nafi Tschelebi (1901-1933), founder of the Islam Institute and the Islam Archive, actively worked towards what he called "a fruitful, healthy synthesis of Islamic and European cultures." ${ }^{24}$ His concept included a critical approach to the convert influx. Tschelebi was the first to draft a set of rules for Europeans who wished to become Muslim. In all his considerations, the safeguarding of traditional religion played a leading part. As the Foreign Office observed: "Oriental attempts at modernizing....are also located in circles that want to safeguard the old religious bond, that is to say the religiously minded Arabs, Egyptians, Indians etc., even reaching into the Wahhabi camp."25 Tschelebi was not a Wahhabi. Rather, he combined a rare mix of western-oriented liberalism, religious nationalism, and pan-Islamism.

To complete the picture, we must also mention the Sufi Bewegung e.V. (Sufi movement), founded in 1925 by the missionary Hazrat Pir Inayat Khan (1882-1927). Seeking individual religious experience, this organization did not position itself politically, nor did it attract the attention of the Foreign Office or any of the media. It did, however, cater to the Ahmadiyya mosque. Eight years later, when German politics turned away from liberalism and the persecution

\footnotetext{
22 Moslemische Revue (1925): 20.

23 Jonker, "Laboratory."

24 AA/2: "An Islamic Press Agency in Berlin" (undated).

25 AA/2: "Islamische Verständigungsarbeit in Berlin" (Oct. 1928).
} 
of minorities began, it immediately dissolved itself,, ${ }^{26}$ while at about the same time the Deutsch-Moslemische Gesellschaft e.V. (the German Muslim Society, or DMG) expanded in the direction of spirituality and inclusion. As a result, some of its members, notably Hosseyn Kazemzadeh "Iranschär" (1884-1962), who had been, earlier, a revolutionary congenial to the German government and a creative publisher trying to promote the regeneration of Iran, ${ }^{27}$ re-surfaced in the Ahmadiyya mosque with an experimental mixture of theosophy and Sufi wisdom. ${ }^{28}$

Once established, the Nazi regime set the scene for a very different kind of Muslim leadership, although some years passed before the face of Islam in Berlin started to change. Between 1928 and 1936, the Ahmadiyya missionary S.M. Abdullah (1889-1956) dominated the mission activity; Kheiri left the city in 1929 and Tschelebi drowned in the summer of 1933 while swimming in a nearby lake. In 1930, while the country quickly moved towards National Socialism and intellectuals of the right and left signaled a new atmosphere of "no-nonsense," ${ }^{29}$ meaning that the chaotic market of ideas was abandoned in favor of a single solution, with the help of the Kantian philosopher Hugo Marcus (1880-1966), Abdullah founded the DMG. The initiative attracted a peculiar segment of Berlin society; in its early stages liberals, pacifists, and Nazi sympathizers mingled in a common search for a religious modernity that befitted the present age. From their contributions to the Moslemische Revue, the search seemed to have been truly open-minded, including orientalism, the meeting of "East" and "West," pacifism, gestalt psychology, life reform, rational conduct, different outlines of "future man," and an open sympathy with the newest Nazi reforms-notably hygiene and body culture (see below). Until 1933, the D MG was also widely acknowledged publicly. An inter-religious entrepreneur, Abdullah was repeatedly invited to speak before Catholic, theosophist, and Jewish audiences. ${ }^{30}$ As an active pacifist, he visited international peace conferences and drew up questionnaires to bring out the peace potential of the different world religions. ${ }^{31}$

26 VR Sufi (April 1933).

27 Jamshid Behnam, "Iranshär' and 'Iranshär, Hosayn Kazemzada,"' in Encyclopedia Iranica (2006), 13:535-536, 537-539.

28 Moslemische Revue, issue 3 (1933); issue 3-4 (1935); issue 2 (1936); cf. Jonker, Missionising Europe.

29 Salomon, Der Fragebogen, 242.

30 AMA/Interwar, 4.

31 AMA/Interwar, 5; 12-13. 
In 1933, Muhammed Ali, president of the AAII, assessed the political landslide in Germany, and came up with a positive result:

We welcome the new regime in Germany as it favors the simpler principles of life which Islam inculcates. Islam's great contribution to the civilization of the world is its solution of the wealth problem and the sex problem..... So far [as] we can see, Germany under the new regime is tackling both the wealth and the sex problem in an Islamic spirit, and there is every hope that in the future the whole of Europe would follow in its wake..... ${ }^{32}$

Thus fortified, the DMG continued to study and to single out aspects of European modernity. On the surface, nothing changed.

However, in 1935 the DMG shed the last of its liberal and pacifist members, among them the philosopher Marcus, a former Jew who had played a major role in shaping the religious search. After repeatedly receiving accusations from IG B members that the DMG "shelter[ed] communists and Jews," Abdullah wrote to the Foreign Office to introduce a new DMG board. His enumeration of the party membership reads like a directory of main Nazi organizations: "Our president Mr Boosfeld is [a] member in the Opfer-Kreis für die Nationalsozialistische Partei; our second secretary Dr Klopp von Hofe is [a] member of the NSDAP and the ss; the treasurer Mr Schubert is [a] member of the Arbeitsfront, and the first assessor, Mr Beier is member of the NSDAP."33

About the same time a man called Habibur Rahman (1901-?) appeared on the scene, incorporating the novel kind of leadership that Nazi politics allowed. Rahman was an Indian Muslim and comrade-in-arms of the future founder of independent India, Subha Chandras Bose. ${ }^{34}$ He was already studying in Berlin when Abdul Jabbar Kheiri set up the IGB,$^{35}$ but for a long time he remained invisible on the organizational level. In 1936, Rahman revived the IGB, which

32 Moslemische Revue 2-3 (1934): 45-46; AMA/Interwar, 5.

33 AA/3 (31 August 1936). NSDAP = Opfer-Kreis für die National-Sozialistische Deutsche Partei ("Circle of Victims of the National Socialist German Party"). The NSDAP was founded in 1920; it engaged in anti-Semitism and street terror, and soon attempted a coup under the leadership of Adolf Hitler. Members who were imprisoned on account of this coup later acquired the status of victim; ss = Schutzstaffel der NSDAP ("Protective Arm of the NSDAP"); Arbeitsfront (“German Work Front”). The latter was founded in 1933, a few days after the annihilation of the trade unions.

AA/3 (20 March 1936); Jan Kuhlmann, Subhas Chandra Bose und die Indienpolitik der Achsenmächte Zeitgeschichte (Berlin: Verlag Hans Schiler, 2003), 343.

VR IGB: $7-8$. 
had been inactive after Kheiri's departure, and acted as its secretary general until, in 1938, he was elected president. ${ }^{36}$ Two years later he was also elected president of the Islam Institute, thus uniting the two organizations under one umbrella. ${ }^{37}$

Profiting from a political atmosphere that encouraged denunciation, Rahman made ample use of it to reach his goals. Between 1935 and 1939, he wrote many letters to the Foreign Office and major Arab and Indian dailies in which he denounced the Ahmadiyya for performing an "unscrupulous mission" and fostering "criminal, communist, and Jewish elements." 38 Rahman also tried to incriminate the Ahmadiyya missionary Abdullah whenever he could, claiming that the latter played tennis with his wife when "normal" Muslims were praying, that Abdullah sold pork, and had illicit contacts with German women. ${ }^{39}$ Rahman's missionary activity was limited to damaging the Ahmadiyya successes. Continuing Tschelebi's approach to converts, he also further restricted conditions on those who wanted to embrace Islam (see below).

Habibur Rahman strove for acknowledgment as the main Muslim representative vis-à-vis the Nazi regime. Although he closely cooperated the Mufti of Jerusalem Amin al-Husseini, who was favored by the Nazis, his own role in the war remained minor. ${ }^{40}$ Politically, Rahman seems to have embraced a mix of nationalist and pan-Islamist positions, and, like so many others around him, exchanged communism for fascism in response to the Nazi pressure.

\section{Converts to Different Muslim Modernities}

The mission advances of Abdul Jabbar Kheiri, head of the IGB, and those of Sadr-ud-Din, head of the Ahmadiyya mission, drew very different crowds; these differences continued to deepen as their places were taken by Habibur Rahman and S.M. Abdullah. Only three of Kheiri's converts, Albert Seiler, Khalid Banning, and Maria Hesselbach switched to the Ahmadiyya, while only

36 VR IGB: $184-199$.

37 VR IIB: 1939.

38 AA/4 (22 March 1937).

39 AA/4 (Aug.-Sept. 1936).

40 In 1936, Hafiz Abdul Rahman Peshawari, leader of the Afghan pan-Islamist movement, warned the Foreign Office against him, stating that Rahman was "a Luna park dancer and a communist" (AA/4: 20 March 1936). Spotting him as a troublemaker and denunciator, the Foreign Office kept its distance (AA/4: 1936, et passim). Rahman ended up working in the war propaganda department. 
one new Muslim from the ranks of the Ahmadiyya (Georg Konieczny) joined the IGB. The majority of the two convert circles kept their distance from each other. As we saw, the main distinction between the two mission approaches was in their position on British India, where the progress of Islam and the betterment of the political situation were interlinked. The very different solutions each put forward - world revolution versus individual progress- had different implications for the modernization of the world and the place of the German Muslims therein. To this, converts added their own distinctions. Whereas the IGB attracted the student generation born after 1900, the Ahmadiyya appealed to members of the upper middle class, many of whom were born in the last decades of the nineteenth century. In the aftermath of the war, the former age group was branded "Generation 1902" because it was too young to have experienced the front line and consequently could not claim heroic deeds; while the latter had fought in the trenches of northern France and Galicia, an experience that had utterly destabilized their lives. In this section, we encounter the two age groups at several intersections of their time line, and seek to understand how they experimented with religion in order to remedy their needs in ways that modernity allowed for.

\section{IGB-Islamia-Islam Institute}

Among the young who felt attracted to Kheiri's revolutionary message were students and artists trying to escape the German isolation that was developing; they were critical of western civilization, dared to articulate anti-war views, and to all appearances felt thrilled to join a non-European international movement. From the scant biographies that remain, one gains the impression that for them, joining Islam first of all implied joining the anti-colonial struggle in support of the liberation movements in North Africa and British India. Some fifty German and Eastern European students, flanked by a few of the older generation, first joined the IGB, then regrouped in the student organization Islamia, then finally broke away from Kheiri in 1927 by setting up the Islam Institute. Who were they?

At the height of Abdul Jabbar Kheiri's quarrel with the Islamia, ${ }^{41}$ he released a list of active IGB members, ${ }^{42}$ and acccused German Muslims especially of

41 The list features a mix of Muslim émigrés and new Muslims and numbers 163 members, a quarter of whom had European names. In the ensuing correspondence ten additional new Muslims were included. Some of the known members however, notably the women of converted couples, are never mentioned.

42 VR IGB: $159-64$. 
communism and "frequent contacts with Moscow."43 In these correspondences, the reader encounters a string of German Muslims: Dr H. 'Khalid' Banning, Ewald Brendel, Helene Bosner, Anton Dybe, Adelheid Cappelle, Albert Fischer, Dr Käthe Göritz, Friedrich 'Hassan' Heinze, Erna 'Hedije' Hoeftmann, Walther 'Hassan' Hoffmann, Bruno Kramer, Hans 'Ali' Knofke, Erwin 'Hossein' Neumann, Bruno Richter, Elsa Schiemann, Hermann Schulz, Albert 'Chalid' Seiler, Werner Voigt, Ulla Westermann, and others. ${ }^{44}$ Across the sources, we count at least two artists and painters (Bruno Richter, Elsa Schiemann), two publishers and art printers (Anton Dybe, Albert Seiler), and a string of dissertation students. Käthe Göritz, Werner Voigt, and Erwin Neumann deposited their dissertations in the Berlin National Library. Erna Hoeftmann, Albert Seiler, and Bruno Richter were affiliated with the university Institute of Oriental Studies. ${ }^{45}$ Some can be traced throughout the records of interwar Islam, notably Walther Hoffmann, Bruno Richter, and Albert Seiler, who never tired of novel attempts to re-shape the Berlin Muslim community. Of this circle, only Anton Dybeand Georg Konieczny re-emerged after the war to help restore Muslim life in Germany. ${ }^{46}$

The list features only two well known names, that of Leopold Weiss/ Muhammed Asad (1900-1982) and Lev Nussimbaum/Esad Bey (1905-1942). ${ }^{47}$ Raised in different Jewish milieus - Weiss in Lemberg, Nussimbaum in Kiev or Baku ${ }^{48}$-both arrived in Berlin with the first waves of Russian refugees. They arrived with nothing, took up oriental studies, and eventually became journalists with an oriental assignment. Both embraced Islam, but it seems that they

43 AA/2 (17 Dec. 1928).

44 After Kheiri quarreled with the Islamia, he wrote adopted Muslim names in parentheses only.

45 VR SOs: $53,57$.

46 Mohammed A. Hobohm, Neuanfänge muslimischen Gemeindelebens nachdem Krieg, 2000.

47 Günther Windhager, Leopold Weiss alias Muhammad Assad (Wien: Böhlau, 2003); Tom Reiss, Der Orientalist. Auf den Spuren von Esad Bey (Berlin: Osburg Verlag, 2008); Gerhard Höpp, Moh. Esad Bey: Nur Orient für Europäer? (unpublished Ms), 1995; Gerhard Höpp. "Noussimbaum wird Essad Bey. Annäherung an eine Biographie zwischen den Kulturen," Moslemische Revue (1996): 18-26.

48 In his first book Oil and Blood in the Orient (1928), Nussimbaum poses as the heir to an old Azerbaijani Muslim oil dynasty in Baku. But in 2009, Fuhrmann, himself an economist with Azerbaijani specialization, claimed to be in possession of Nussimbaums' birth certificate from a Kiev synagogue. For reasons of his own, he did not publish this document. Fuhrmann did publish an internal report of the German Secret Service (Gestapo), which in 1935 had arrived at the same conclusion (www.essadbey.de). 
had very different reasons. Thirty years later, Weiss describes in his autobiography his conversion experience, an intense moment in which he rejected western civilization, in which he suddenly "saw" the lack of fulfillment and the unhappiness of the wealthy Berliners sitting next to him in the U-Bahn. ${ }^{49}$ In very different fashion, Nussimbaum experimented with an exotic sounding name, weaving a fable of his oriental origin as he went along. Originally, he seems to have made a living in the Romanische Café, where he recited oriental stories in appropriate garb to the assembled bohemia. ${ }^{50}$ Later on, he outright denied his conversion, and claimed to be the offspring of a Azerbaijani Muslim oil millionaire in Baku, and a Russian bolshevist mother who happened to be imprisoned in that city at the time of marriage. ${ }^{51}$

Weiss/Asad and Nussimbaum/Esad Bey were migrants from Eastern Europe. Scrutinizing Kheiri's list, it seems that other Eastern Europeans accompanied them. The reader meets with Helene Adas, Ewald Brendel, Albert Ceasar Czernikow, Viktor Glikin, Leon Jekelzewitz, Arpad Jerenzz, Diodor Kopinski, Leowar Mirimanian, Melly Podleschewsky, Paul Warkoicz, and Eugenie Woranoff, none of whose lives could be reconstructed. Many of these family names can be traced to the passenger lists of steamers that left weekly for America. A survey through the North and South American Jewish communities suggests that many of them had Jewish roots as well.

Kheiri's ambitious plans ultimately came to nothing. Isolated after a nasty dispute over the abolishment of the khalifate, he discontinued not only the mission journal but also the yearly IG B gatherings. ${ }^{52}$ In the end, Nafi Tschelebi, the student leader of the Islam Institute, dethroned him. Tschelebi's idea of Muslim modernization was not world revolution, but the laying of foundations for future Muslim nation states. Although accused of receiving money from Moscow, ${ }^{53}$ he nonetheless acquired the trust and cooperation of important German institutions, and in only a short period of time created the Islam Institute, the Islam Archive, two periodicals, and a closely-knit local network. Tschelebi managed to give a different focus to the development of Muslim modernity in Berlin. In their estimate of the political situation, the Foreign Office judged his circle "to have completely distanced itself from the 'world

\footnotetext{
49 Muhammad Asad, The Road to Mecca (New York: Simon \& Schuster, 1993), 174-177.

$50 \quad$ Reiss, Der Orientalist, 256.

$51 \quad$ Esad Bey. Öl und Blut im Orient. Meine Kindheit in Baku und meine haarsträubende Flucht durch den Kaukasus (Munich: Deutsche Verlagsanstalt, 1930), 17; Wilfried Fuhrmann. Plagiat, Lüge oder Vertrauen? Wo ist Essad-Bey? Available online: www.essadbey.de.

52 Jonker, Missionising Europe.

53 AA/2 (17 Oct. 1928), 3.
} 
revolutionaries' and their political-military illusions, which dominated the war and the post war period," and decided that the time had come "to begin a fruitful cooperation." 54

The Islam Institute indeed became an attractive place for many different people. The director of Das Seminar für orientalische Sprachen (Institute for Oriental Studies) at Berlin University, Prof. Kampffmeier and member of Parliament Julius Bachem sat on the board; Walther Hoffmann, Bruno Richter, and Georg Konieczny served as authors, editors, and printers of its periodicals. From the Middle East, Weiss/Asad and Nussimbaum/Esad Bey contributed articles; Erna Hedije Hoeftmann and Albert Chalid Seiler were commissioned to run a convert register and to "rethink the relationship between old and new Muslims." 55 With a view to the convert influx, this was a novel policy, and pointed towards restriction: "Inscribed in the register may be those who are able to give proof of exit from their former religious community and proof of entry to Islam. ${ }^{\prime 56}$ The phrase dips into the sensitive subject of religious belonging, revealing the fact that many new Muslims did not deem it necessary to exit from their former religious communities. Rather, as I discuss in the next section, German religious seekers preferred to move from one religious community to the next, without binding themselves.

Nonetheless, whereas many of the Muslim émigrés only stayed for the duration of their university study, German Muslims guaranteed continuity and durability for the community. There is no doubt that this circle served to anchor the Muslim community in Germany. They adopted the roles of navigator, cultural translator, and interpreter in the local framework and engaged in the transfer local knowledge. In contrast to Muslim émigrés, local Muslims knew all about the legal requirements and the political and societal expectations surrounding the founding of migrant organizations.

Khalid Banning, for instance, navigated the proceedings, which led to the foundation of the IGB. ${ }^{57}$ Hoffmann, his wife Emina, Erna Hoeftmann, and Seiler supported Nafi Tschelebi in breaking away from the IG B. ${ }^{58}$ Hoffmann even took it upon himself to file a complaint. ${ }^{59}$

\footnotetext{
54 AA/2 (17 Oct. 1928), 1.

55 Die Islamische Gegenwart. Monatszeitschrift für die Zeitgeschichte des Islam, ed. M. Nafi Tschelebi and Muhammed Hassan Hoffmann (Berlin, 1929), 1.

56 Die Islamische Gegenwart, 1.

57 VR IGB: 8 .

58 VR IGB: 20.

59 VR IGB: 58, 66-70, 79, 94-95, 104.
} 
In the mid-1930s, Hoffmann and Konieczny also supported the revival of the IG B by Habibur Rahman. Hoffmann, a former communist, sat on the board. Secretary Konieczny signed his letters with "Heil Hitler!,"60 was active in different Nazi organizations, and also acquired NSDAP membership. ${ }^{61}$ Seiler, by then head of the DMG but equally supportive of the Islam Institute, pleaded for amalgamation with the IG B, a suggestion the DMG board utterly rejected. ${ }^{62}$ For their part, Muslim émigrés increasingly considered German Muslims as insignificant. When, on 27 May 1940 Rahman finally attempted to fuse the IG B with the Islam Institute, thus creating the platform that was to be the official Muslim representative vis-à-vis the war ministries, none of them were invited any more.

\section{Ahmadiyya Lahore and the DMG}

How can one recognize a convert? The answer to this question very much depends on how the act of conversion is defined. Over the last hundred years, sociologists of religion came up with many definitions, from "a radical change of consciousness in which the individual changes both his world view and his identity," to "socially embedded happenings which are communicated through group belonging, narrations of the self and demonstrative acts." ${ }^{\prime 3}$ For some, conversion is a communicative act, for others, it signals deep psychic change. For scholars who occupy themselves with boundary marking, converts are radical transgressors of cultural borders: they quit their traditional (religious) habitat in order to adopt the space of the other. ${ }^{64}$ Seen through this lens, bodily signs that broadcast one's new solidarity seem to be a necessity: otherwise, how can the adopted community recognize that the newcomer is one of them?

Turning the pages of the Moslemische Revue, that necessity is utterly absent. Many Germans accepting Islam with the help of the Ahmadiyya missionaries published a photograph in this journal, which they labeled with their real or adopted names. In addition, some added a conversion narrative. Others wrote learned articles on aspects of Islam, in which the reader easily detects autobiographical traces. In all, fifteen individual photographs were published. Some of

\footnotetext{
6o VR IGB: 1935 .

61 Barch B: Nr.4831277.

62 VR DMG (Sept. 1938).

63 Detlev Pollack, "Was ist Konversion?" in Treten Sie ein! Treten Sie aus! Warum Menschen ihre Religion wechseln, ed. Hanno Loewy, et al. (Berlin: Parthas, 2012), 44.

64 Michele Lamont, "The Study of Boundaries Across the Social Sciences," Annual Review of Sociology 28 (2002): 167-195.
} 
those portrayed appear alone, others with Sadr-ud-Din. Two newly wed couples pose in front of the mosque. One photograph portrays a whole family.

In line with the missionaries view that "becoming a Muslim does not require a transformation" (see above), those portrayed did not stress their transgressions anywhere. They are neither adorned with 'Islamic' elements, nor do they dress up in any other special way. "Dr H. Khalid Banning," for instance, looks very much like the public prosecutor he probably was (1924). ${ }^{65}$ Banning posed with "Muhammed Taufiq Killenger," a gentleman with a military demeanor, described in an undated Ahmadiyya pamphlet from the 1930s as an adventurer who had served in different armies around the world, including the Hungarian, Austrian, Swiss, Dutch colonial, Venezuelan, and Ottoman armies. ${ }^{66}$ In 1938, he surfaces again as M.T. Killinger, enthusiastically welcoming the Nazi occupation of Sudetenland. ${ }^{67}$ During World War II, already an old man, Killinger repeatedly offered his service to the ss, which eventually employed him as director of the ss imam training. ${ }^{68}$

In the next issue, we meet with very different characters. One calls himself "Konrad Giesel," and holds a book in his hands, on which is written "With Islam, 1.X.1924." We can identify him as Konrad Algermissen, a Roman-Catholic priest who during the 1920 published a series of sociological studies on different religious "sects" with Giesel Verlag. His photograph evokes the German intellectual; in the accompanying analysis, "Thoughts on Community," Algermissen enthuses about the community potential of Islam. ${ }^{69}$ In contrast, Hanns Lobauers' photograph corroborates his self-description as a tormented Prussian officer who lost himself in the trenches. ${ }^{70}$ Only one of the ladies of this early period has wrapped herself in a kind of Indian cloth. The other two

65 There is a Dr H. Banning in the 1924 Berlin address book who lived in the Wilmersdorf borough and practiced as a public prosecutor. Since most visitors of the Wilmersdorfer mosque lived within walking distance, there is fair chance he is the same one.

$66 \mathrm{AA} / 5$.

67 "Endlich sind wir im Reich!" (Finally we are in the Reich!), Moslemische Revue (1938), 94. For 1934, we find Fischer's name on the DMG board, proof that for some time at least he was an active member.

68 Pieter Sjoerd van Koningsveld, "The Training of Imams by the Third Reich," in The Study of Religion and the Training of Muslim Clergy in Europe: Academic and Religious Freedom in the 21th Century, ed. Willem B. Drees and Pieter Sjoerd van Koningsveld (Leiden: Leiden University Press, 2008), 348-368.

69 Moslemische Revue (1925): 25-28.

$70 \quad$ Moslemische Revue (1926): 34-38. 
present the image of well-dressed upper middle-class women with short hair, and wearing pearls. ${ }^{71}$

The pattern repeats itself in the portrayals of the early 1930s. "Saffiah Irma Gohl, stud. Phil." commissioned an art photograph in which she poses as a modern German woman with a flowery band in her short hair (1931). In her conversion narrative Saffiah describes her religious quest as "a journey" past Buddha, Zoroaster, and Confucius, through the cliffs of Egyptology, Oriental Studies and Arab literature, until she finally encountered an Egyptian who became her spiritual mentor, and eventually her husband. ${ }^{72}$ In 1944, the two of them directed an inflammatory protest to the League of Nations, describing in detail the "havoc and ruin" caused by the Italian armies in Tripoli. ${ }^{73}$ Of all the German converts, she was the only one who engaged in resistance against the Nazi regime.

Also in 1931, the Moslemische Revue finally featured an oil painting of the founder of the DM G: "Dr Hamid Marcus, President of the Deutsch-Moslemische Gesellschafte.V." We behold him in the typical posture of Germany's poets and thinkers, outstretched fingers against his temple, books in the background, and a furrow between his brows.

In the scant remains of the interwar mosque archive his handwritten conversion narrative, dated 1931, survived, and corroborates his self-conception as 'thinker.' ${ }^{44}$ Studies on conversion often stress that the blueprint of any conversion narrative is a transformation from crisis to salvation, followed by the urge to give witness. ${ }^{75}$ Differently, but much in line with Ahmadiyya philosophy, Marcus stated that his journey to Islam was neither governed by crisis (like Lohbauer and other soldiers who served at the front), nor by a spiritual journey (like Gohl and others who used theosophy as a vehicle) but by continuation. As a philosophy student, he had embraced Kant, Nietzsche, and Spinoza and developed the philosophy of "mono-pluralism," and thus created the foundation of a severe kind of monotheism as he progressed. In this self-portrait he could therefore rightly stress that, while encountering Islam in the person of Sadr-ud-Din, he only re-discovered his philosophical roots.

Marcus also had Jewish roots, a fact that on the surface does not seem to have played a role in his writings. His biography still remains to be written, but

\footnotetext{
71 Moslemische Revue, photographs preceding the 1924 and 1925 issues.

72 Moslemische Revue (1931): 56-59.

73 AMA/Post-war: 2.

74 AMA/Interwar: 7 .

75 Andreas B. Kilcher, "Konversion als Erzählung," in Treten Sie in! Treten Sie aus! Warum Menschen ihre Religion wechseln, ed. Hanno Loewy et al. (Berlin: Parthas, 2012), 50-64.
} 
from his many contributions to the Moslemische Revue it is already clear that this philosopher searched for a modern religious foundation, which had outgrown the old religions, and from which could grow up as a "novel man." "Where and who are the people for whom it is worth to (re-) shape the world into a paradise? Where are these people to whom belongs the future as we want it?" he asks in "Religion and Future Man," to which he answers himself: "We will not find them, we will have to create them first."

In the last years of the Weimar Republic, Hugo Hamid Marcus truly was not the only one who raised this question. 'Novel man,' 'novel leadership', and 'people of the future' were the catchwords that governed the politics of the day, which appeared in a multitude of book titles and stood for visions of the future that ranged from modern to anti-modern, from liberal to conservative, from the far right to the far left. ${ }^{77}$

The difference between Marcus' vision, as laid down in his writings for the Moslemische Revue, and the solution that in 1933 forced its way to political power, must be sought in the open-minded curiosity with which this philosopher tried to bridge not only East and West, Christianity and Islam, but also left- and right-wing ideologies. Marcus, himself born in 1880 and a veteran of the Great War, believed in the creative powers of a young generation that had been molded by a religion that embraced rationality as well as modernity, practical humanitarianism as well as spirituality. From his writings it becomes clear that this could only be Islam.

But creating the "future man" was still very much a work in progress, its result open-ended. For the moment it led to very different profiles. Returning to the photo gallery displayed on the pages of the Moslemische Revue, two men of that young and coming generation still need to be highlighted. At the time, they seemed to incorporate the ideal Marcus envisioned.

One year after Marcus' publication, Rolf von Ehrenfels, born in 1901 in Prague, son of the gestalt therapist Christian Baron von Ehrenfels, at home in the literary and bohemian circles of Vienna, Prague, and Budapest, answered with "Islam and the Young Generation in Europe."78 Positioning himself as a man of the future, von Ehrenfels drew a parallel between Islam and certain aspects of the European Lebensreform (life reform). Among others, he addressed erotic communication, respect for the earth, the ways in which peo-

$76 \quad$ Moslemische Revue (1930): 66.

77 Friedbert Aspetsberger, 'Arnolt Bronnen.' Biografie (Wien/Köln/Wiemar: Böhlau Verlag, 1995), 412; Maser, Adolf Hitler, 315-316; Kurt Hiller, Leben gegen die Zeit. Erinnerungen (Hamburg: Rowohlt, 1969), $218 \mathrm{f}$.

78 Moslemische Revue (1931): 81-91. 


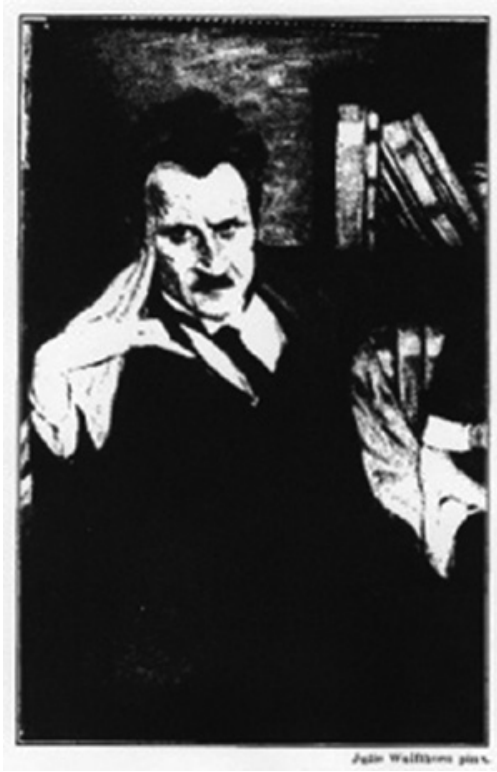

Figure 2.1 Hugo Hamid Marcus (1929). Moslemische Revue 1 (1931), p. 1 COURTESY NASIR AHMAD

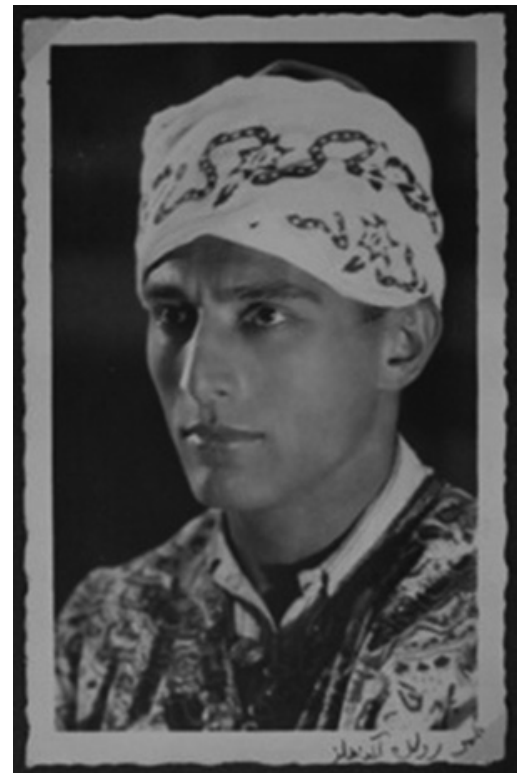

FIGURE 2.2 Rolf Umar Ehrenfels (1926). In: photo album "Mosque \& Friends", Oettinger Archive COURTESY SUHAIL AHMAD

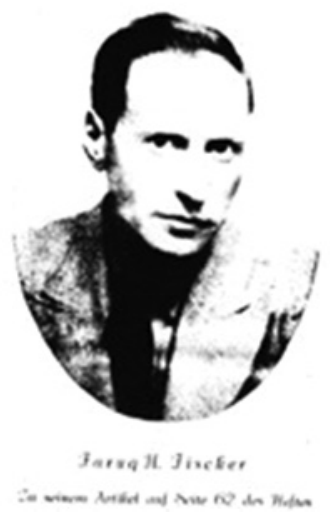

FIGURE 2.3

Faruq H. Fischer (1934). Moslemische Revue 2 (1934), p. 1 COURTESY NASIR AHMAD 
ple greet each other, dress themselves, and shape their house interiors, and thereby create a framework in which they live and communicate. Islam, he concluded, is modern because it possesses the potential to shape life in ways that are recognized as progressive in Europe. In 1931 von Ehrenfels was not yet an anthropologist, but the theory behind the article points to the future; it was already his conjecture that material frameworks shape and direct human communication and experience. In a typical fashion, von Ehrenfels' own encounter, which made him decide to embrace Islam in the first place, was an intensive experience of mosque architecture that resulted in a thick description that betrays the influence of gestalt therapy. ${ }^{79}$

Although von Ehrenfels was appointed co-editor of the Moslemische Revue and wrote several articles for the journal, he never published his photograph. We only know his contemporary face from his journey to Lahore in 1933, when he met with figures from the Ahmadiyya mother organization, and from some earlier photographs published in the Nussimbaum biography. 80

Some years later, the editors of the Moslemische Revue thought to recognize another "future man" in the popular author "Faruq H. Fischer." Invited to present a piece on the occasion of the ten-year celebration, they announced him as "the well-known author, one of the youngest Europeans who have gladly embraced Islam" 81 The accompanying photograph bears the traits of a sleek and calculating Nazi youth; his name can be traced to Hans Fischer who, in 1932 and 1933, was one of the up-and-coming young men of popular Nazi ideology. His many theater plays, advertised with titles like Jung Deutschland voran ("Young Germany to the fore"),Deutschland's Morgenrotentflammt! "Germany's dawn ignites!"), or Heb' deine Flügel, deutscher Adler...("Raise your wings, German eagle...") are full of blood and earth symbols and ugly examples of anti-Semitism, which he employed for comic effect.

What did this "future man" write for the Moslemische Revue? His contribution was titled "Does Islam 'lack modernity'? - A parallel between the old religion and Europe of the present." ${ }^{82}$ In its pages, Fischer, like von Ehrenfels, sets off to find parallels between Islam and examples of modern European-ness but unlike von Ehrenfels, in Fischer's world 'modern' is everything that Nazi ideology stands for: Islam forbids alcohol? No problem! “The Führer of the German

\footnotetext{
79 Moslemische Revue (1930): 98-105.

$80 \quad$ Reiss, Der Orientalist, 363 .

81 Moslemische Revue (1934): 62. For 1934, we find Fischer's name on the DMG board, proof that for some time at least he was an active member.

$82 \quad$ Moslemisch Revue (1934): 62-73.
} 
people does not take one single drop!" 83 or, "Does Islam lack progress? Certainly not! Europe adopts more and more Islamic thought." ${ }^{84}$ Instead of intellect and liberalism, Fischer writes, Nazism propagates hygiene, sports, and attachment to the earth; instead of individualism, it cultivates group experience. ${ }^{85} \mathrm{To}$ Fischer, this is what Islam is all about: "Not modern? Never! Not civilized? Never! Otherwise, our statesmen would not act in an Islamic way. Are you not modern? Am I perhaps not modern?"86

\section{Shaping Religious Modernity}

From our visit to the photo gallery of the Ahmadiyya mission journal, it becomes clear that 'their' new Muslims did not adopt any visible Islamic attributes because, first, it was the Ahmadiyya view that "becoming a Muslim does not require a transformation," and second, because the Germans thought that their entry necessitated a range of changes for Islam as a matter of course. For the circle of Muslim émigrés who gathered in the IGB, the German enthusiasm to join Islam thus acquired an uncomfortable edge. In their view, the way converts in the Ahmadiyya mosque communicated about Islam and the courses to progress they suggested, were not only unrecognizable to 'real' Muslims, but they should be downright rejected.

Early in 1937, Habibur Rahman sent a 10-page paper to the Foreign Office in which he once again summarized his grievances against the Ahmadiyya. ${ }^{87}$ The Ahmadiyya, he states, present a serious disturbance in Berlin, not only because they possess the only mosque but also because the ways in which they shape Islamic communication angers IG B Muslims to the extent that they refuse to pray there. "Disturbing" is the "shameless, indiscriminate mission activity," which attracts "criminal elements such as Jewish and communist agitators." 88 By way of solution, Rahman suggests that the influx of converts should be strictly controlled, and that this control should be based on the rules already laid down in the renewed founding protocol of the IG B. ${ }^{89}$ This document stipulates that converts should not only give written proof of

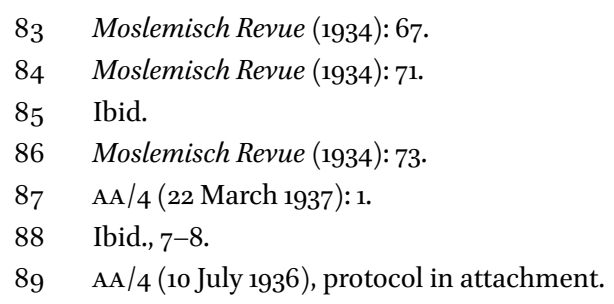


their exit from their former communities and their entries into the Muslim community, as Tschelebi already decreed, but they must also prove "flawless conduct for a period of two years," give "written consent to adopt a Muslim name," and establish "serious attempts to acquire one of the oriental languages." 90

Why did Rahman bear down on converts in a manner that seems designed to prevent them from becoming Muslim at all? Despite the tirade of hate with which the author attacked his opponent, despite his obvious desire to obtain the mosque, there is an element in this text that touches upon the very nature of religious renewal itself.

In an article headed "We Require a Mosque in Berlin," appearing some weeks later in The Star of India, he or one of his circle explained the rationale behind his statement. For example, the author deplores the sense of foreignness one may feel when visiting the discussion circle in the Ahmadiyya mosque, and when participating in prayer he even detects something decidedly un-Islamic:

If (...) a Muslim pays a visit to one of the conferences which are held on Friday evening in the mosque or in the house of the Imam, he will probably find there a Christian lady or gentleman delivering a speech about beautiful landscapes in foreign countries, about the political situation in India, about Persian Poets and all sorts and kinds of subjects of more or less general interest. Real Islamic instructions and information are hardly ever given and if so, the subject will mostly serve to cover up the difference between Islam and Christianity. ${ }^{91}$

Partaking in the Friday prayer presents another shock: "To take part at the congregational Friday Prayer is impossible for an orthodox Muslim.... The few Muslims see themselves, during the prayer, surrounded by a crowd of nonMuslims, sitting on benches and watching 'the performance."'92

This, the author concludes, cannot be true Islam. These performances definitely give a false impression of what real Islam was about: "Under those circumstances, the Berlin mosque...can never be the center of the Muslim community."93

Whoever wrote this article certainly had been an intimate observer of the comings and goings in the Ahmadiyya mosque and mission house. However, in

\begin{tabular}{ll}
\hline 90 & Ibid. \\
91 & AA/4 (21 April 1937). Newspaper clipping in attachment. \\
92 & Ibid. \\
93 & Ibid.
\end{tabular}


contrast to the move toward modernization, which both Europe and the Muslim world overwhelmingly desired, Habibur Rahman and those around him seem to have held up a frozen, timeless image of Islam, which they 'knew' by right of birth. Acting along the lines of purity and danger (Mary Douglas), this circle set out to re-draw its borders without even discussing their views openly. At least we do not find any evidence of such discussions among the many comments on lectures held in the mosque. Rahman's main instrument of communication exhausted itself in a rhetoric of hate, of which many instances survive.

Unfortunately the times were propitious for him. Muslim émigrés in Berlin who suspected converts of eroding 'their' religion expected Nazis to support them. But their extensive cooperation during the war falls outside the scope of this contribution; this is treated elsewhere. ${ }^{94}$

There exists a group photograph in the Moslemische Revue, dating 1936, in which we see the DMG community listening to a sermon in the mosque. ${ }^{95}$ The viewer beholds European men and women sitting on wooden chairs in close proximity to one another. Although it seems to be cold and the congregation huddles in winter coats, many of the women are bare headed, as are the men. In front of the pulpit one catches a glimpse of two men in Arab headgear sitting on the floor. Is this what our author is talking about? On close inspection, the congregation gives a vaguely Lutheran impression but there is also no doubt that these are Muslims celebrating the annual Eid festival. What can be seen then is an instance of modern Muslim ritual communication. It is but one instance of the bridge the Ahmadiyya tried to build between East and West, Christianity and Islam, between the need for modernization in the Muslim world and European visions of progress and of the "future man."

\section{Conclusion}

Religion is not a primordial entity thrown into the world from outer space. In the eyes of its adherents it may be inspired, even ruled by divine power. But the ways in which this inspiration takes form is entirely a matter of human creativity. Every religion has appeared in a specific societal setting, creating a tradition that shaped social communication, and in its turn was shaped by society. As societies change, reform and renewal of that tradition constitute a necessary and never-finished task.

94 Jonker, Missionising Europe.

95 Moslemische Revue (1936): 1. 
In this contribution I have shown that in Berlin Muslim missionaries from British India fostered different ideas of how to modernize their home country; they envisioned a struggle that involved the modernization of Islam as a central feature and they invited the Germans to join in this effort. In the early 1920s, when revolutionary movements still held Germany in their grip, Kheiri's invitation to 'world revolution' attracted a circle of German and eastern European students, intellectuals, and artists. In a very different fashion, Sadrud-Din approached modernization from the viewpoint of personal progress: all the German seekers had to do was find the 'right' roots in themselves.

But missionaries were not alone in searching for change. Between the Great War and the chaos that engulfed the world in 1939, many Germans also desperately groped for ideas that would allow them to help shape the future in ways they deemed appropriate, in ways that utilized pacifism, that would bring progress, bridge the East and West, and represent a meeting of minds, foster personal well-being, and provide for peoples' spiritual needs. Borrowing from, even transgressing on other religions was only one means to this end. Such Germans considered "being modern" a method of achieving personal progress and a shield against all those who wanted to turn back the clock and re-establish the traditions and power structures of a bygone age.

In the tumultuous years at the end of the Weimar era, when an aggressive authoritarian form of modernity took hold of the masses, this "religious market" was put to the test. It was not only the Indian Muslims in Berlin; the Arab, Afghan, and Tatar Muslims were also focused on reforming their homelands and making them politically independent. Islam was assigned very different roles in that process. The Muslim émigrés who gathered in the IGB perceived their religion as something that bonded them together, but which did not necessarily call for outward change. By siding with the Nazi regime in an attempt to gain power, the IGB even tried to ward off renewal and withdrew to a primordial vision of 'pure Islam.'

In contrast, Ahmadiyya Muslims tried to build a bridge between different cultural traditions with the aim of fertilizing and reforming both Christianity and Islam. In the interwar years this was their hallmark of religious modernity. Acting in a political constellation in which missionaries and converts embraced personal progress as the essence of modernity, conversion itself became a two-way process. And herein lies the meaning of Ahmadiyya activity for European (trans)cultural history: In their attempt to cross the gulf between East and West, missionaries smoothed the way, borrowing from, and adapting to western thought wherever it was of use. By paralleling religious with intellectual exchange, missionaries allowed their converts to adapt Islam's foreign 
knowledge, ritual, and moral traditions to more familiar patterns. What they shared, their common ground so to speak, was a taste for experiment. In a joint effort, missionaries and converts created a totally different image of Islam, one in which Germans marveled and in which they were able to find consolation.

In retrospect, Muhammed Ali's welcome of the new regime in 1933 because of its "tackling the wealth and sex problem" may sound naïve in the face of the violence that followed. But how was he to know? Did the DMG realize it was playing with fire? Individual members continued to believe that European civilization would be changed by re-modeling the self and shaping a Muslim "future man"; this was a vision strong enough to keep liberals, fascists, and Jews assembled under one roof. The bond lasted until the Nazi element took over in 1935. Taking this into account, the interaction between Muslim missionaries and their host society engendered fresh ideas and knowledge transfers in many different directions. Modernization and progress were the key words around which communication circulated; converts who had surmounted cultural borders simply continued to pursue these central notions in their search for salvation. Muslims like Habibur Rahman, who clung to a primordial image of religion, probably never noticed the momentum and urgency of their quest.

\section{Bibliography}

\section{Primary and Archival Sources}

Muslim (Mission) Journals

Die Islamische Gegenwart. Monatszeitschrift für die Zeitgeschichte des Islam, edited by M. Nafi Tschelebi and Muhammed Hassan Hoffmann. Berlin: 1927-1929.

Der Islam. Ein Wegweiser zur Rettung und zum Wiederaufbau, edited by Jabbar Kheiri and Sattar Kheiri. Berlin: 1922-1923.

Moslemische Revue, edited by Sadr-ud-Din, F.K. Khan Durrani, and S.M. Abdullah.

Berlin: 1924-1939.

\section{Registry Files (VR)}

DGI = Deutsche Gesellschaft für Islamkunde e.V. :VR 26349 (1912-).

DMG = Die Deutsch-Moslemische Gesellschaft e.V. :VR Nr. 8769 (1930-).

IG B = Die Islamische Gemeinde zu Berlin e.V. : VR B Rep. 042 / Nr. 26590 (1922-).

IIB = Islam-Institut zu Berlin e.V. : VR 12354 (1939-) and 95 VR 12941 (1942-).

Sufi $=$ Sufi-Bewegung e.V. 94 : VR 4635 (1925-). 


\section{German Foreign Office (AA)}

AA/1 = AA PA R 782.40. Abteilung III / Akten betreffend Kirchen- und Religionsgemeinschaften / Islam, Volume 1: 1924-1928.

AA/2 = AA PA R 782.41. Abteilung III / Akten betreffend Religions- und Kirchenwesen / Islam, Volume 2: 1928-1931.

AA/3 = AA PA R 782.42. Abteilung III / Akten betreffend Kirchen- und Religionsgemeinschaften, Islam, Volume 3: 1932-1936.

AA/4 = AA PA R 104.801. Politische Abteilung /Akten betreffend Religions- und Kirchenwesen, Islam, 1936-1939.

AA $/ 5$ = AA 60.675 / Akten betreffend Indien, 1942.

Ahmadiyya Mosque Archive (AMA)

AMA / Interwar (1930-1939).

AMA / Post-war (1946-1949).

\section{Bundesarchiv (Barch)}

Abt. Berlin: NSDAP Register

\section{Secondary Sources}

Achcar, Gilbert. Les Arabes et la Shoah. Paris: Actes sud, 2009.

Asad, Muhammad. The Road to Mecca. New York: Simon \& Schuster, 1993 [1954].

Aspetsberger, Friedbert. 'Arnolt Bronnen.' Biografie. Wien-Köln-Weimar: Böhlau, 1995 .

Bauschinger, Sigrid. "The Berlin Moderns: Else Lasker-Schüler and 'Café Culture.” In Berlin Metropolis, edited by Emily D. Bilsky, 58-102. New York: Jewish Museum, 2000.

Behnam, Jamshid. “'Iranshär' and 'Iranshär, Hosayn Kazemzada.” Encyclopedia Iranica (2006), 13:535-536 and 537-539.

Burbank, Jane and Frederick Cooper. "War and Revolution in a World of Empires: 1914-1945." In Empires in World History, edited by Jane Burbank et al., 369-413. Princeton, NJ: Princeton University Press, 2010.

Conze, Vanessa. Das Europa der Deutschen: Ideen von Europa in Deutschland zwischen Reichstradition und Westorientierung (1920-1970). Munich: Oldenbourg Wissenschaftsverlag, 2005.

Doering-Manteufel, Anselm. "Suchbewegungen in der Moderne. Religion im politischen Feld der Weimarer Republik." In Religion und Gesellschaft. Europa im 20. Jahrhundert, edited by Friedrich Graf and Klaus Große Kracht, 175-202. Köln/ Weimar/Wien: Böhlau, 2007.

Dohrn, Verena and Gertrud Pickhan. Transit und Transformation. Osteuropäischjüdische Migranten in Berlin 1918-1939. Göttingen: Wallstein, 2012. 
Esad Bey. Öl und Blut im Orient. Meine Kindheit in Baku und meine haarsträubende Flucht durch den Kaukasus. Munich: Deutsche Verlagsanstalt, 1930.

Fuhrmann, Wilfried. "Plagiat, Lüge oder Vertrauen? Wo ist Essad-Bey?" Accessible online: www.essadbey.de, 2009.

Giljazov, Iskander. Muslime in Deutschland: Von den zwanziger Jahren zum 'Islamische Faktor'während des 2. Weltkrieges (MS, Höpp Archive), 1989.

Hiller, Kurt. Leben gegen die Zeit. Erinnerungen. Hamburg: Rowohlt, 1969.

Hobohm, Mohammed, A. Neuanfänge muslimischen Gemeindelebens nach dem Krieg, 2000. Available online at Geschichte des Islams in Deutschland, accessed 19 April 2015: http://web.archive.org/ web/20070129062534.

Hobsbawn, Eric. The Age of Extremes. A History of the World 1914-1991. New York: Vintage Books, 1994.

Höpp, Gerhard. Arabische und islamische Periodika in Berlin und Brandenburg 1915-1945. Geschichtlicher Abriß und Bibliographie. Berlin: Das Arabische Buch, 1994.

Höpp, Gerhard. Mohammed Essad Bey: Nur Orient für Europäer? Unpublished Ms, private archive Hoepp, in Zentrum Moderner Orient, Berlin, 1995.

Höpp, Gerhard. "Noussimbaum wird Essad Bey. Annäherung an eine Biographie zwischen den Kulturen." Moslemische Revue (1996): 18-26.

Höpp, Gerhard. 'Die Sache ist von immenser Wichtigkeit...' Arabische Studenten in Berlin. Unpublished MS, private archive Hoepp, in Zentrum Moderner Orient, Berlin, 1990.

Höpp, Gerhard. "Zwischen Moschee und Demonstration. Muslime in Berlin, 1922-1930." Moslemische Revue (1990/3): 135-146, (1990/4): 230-223, (1991/1), 12-19.

Horne, John and Alan Kramer. German Atrocities: A History of Denial. New Haven and London: Yale University Press, 2001.

Jonker, Gerdien. "The Dynamics of Adaptive Globalization: Muslim Missionaries in Weimar Berlin." Entangled Religions (2014): 115-158.

Jonker, Gerdien. "A Laboratory of Modernity—The Ahmadiyya Mission in Interwar Europe." Journal of Muslims in Europe (2014): 1-25.

Jonker, Gerdien. Missionizing Europe: The Ahmadiyya Quest for Religious Progress 1900-1965. Leiden: EJ Brill, 2015.

Kheiri, Abdul Jabbar. Sowjet-Rußland und die Völker der Welt. Petrograd: Verlag Kommunistische Internationale, 1924.

Kilcher, Andreas B. "Konversion als Erzählung." In Treten Sie ein! Treten Sie aus! Warum Menschen ihre Religion wechseln, edited by Hanno Loewy, Fritz Backhaus, and Bernhard Purin, 50-64. Berlin: Parthas, 2012.

Klöckner, Michael and Udo Tworuschka. Religionen in Deutschland. Kirchen, GlaubensGemeinschaften, Sekten. Munich: Olzog Verlag, 1994.

Kuhlmann, Jan. Subhas Chandra Bose und die Indienpolitik der Achsenmächte Zeitgeschichte. Berlin: Verlag Hans Schiler, 2003.

Lamont, Michele. "The Study of Boundaries Across the Social Sciences." Annual Review of Sociology 28 (2002): 167-195. 
Linse, Ulrich. “Lebensreform und Reformreligionen." In Die Lebensreform. Entwürfe der Neugestaltung von Leben und Kunst um 19oo, edited by Kai Buchholz et al., 193-199. Darmstadt: Haeusser-media, 2001.

Maser, Werner. Adolf Hitler. Mein Kampf. Geschichte. Auszüge. Kommentare. Rastatt: Moewig, 1981.

Pollack, Detlev. "Was ist Konversion?" In Treten Sie ein! Treten Sie aus! Warum Menschen ihre Religion wechseln, edited by Hanno Loewy, et al., 38-50. Berlin: Parthas, 2012.

Reiss, Tom. Der Orientalist. Auf den Spuren von Esad Bey. Berlin: Osburg Verlag, 2008. Salomon, Ernst von. Der Fragebogen. Hamburg: Rowohlt, 1961.

Schlögel, Karl. Das russische Berlin. Ostbahnhof Europas. Munich: Panthon, 2007. Van Koningsveld, Pieter Sjoerd. "The Training of Imams by the Third Reich." In The Study of Religion and the Training of Muslim Clergy in Europe: Academic and Religious Freedom in the 21th Century, edited by Willem B. Drees and Sjoerd van Koningsveld, 333-368. Leiden: Leiden University Press, 2008.

Windhager, Günther. Leopold Weiss alias Muhammad Asad. Wien: Böhlau, 2003.

Zander, Helmut. "Die Theosophie im Kontext weltanschaulicher Pluralisierung im 19. Jahrhundert." In Anthroposophie in Deutschland. Theosophische Weltanschauung und gesellschaftliche Praxis 1884-1945, 33-51. Göttingen:Vandenhoeck and Ruprecht, 2007 . 